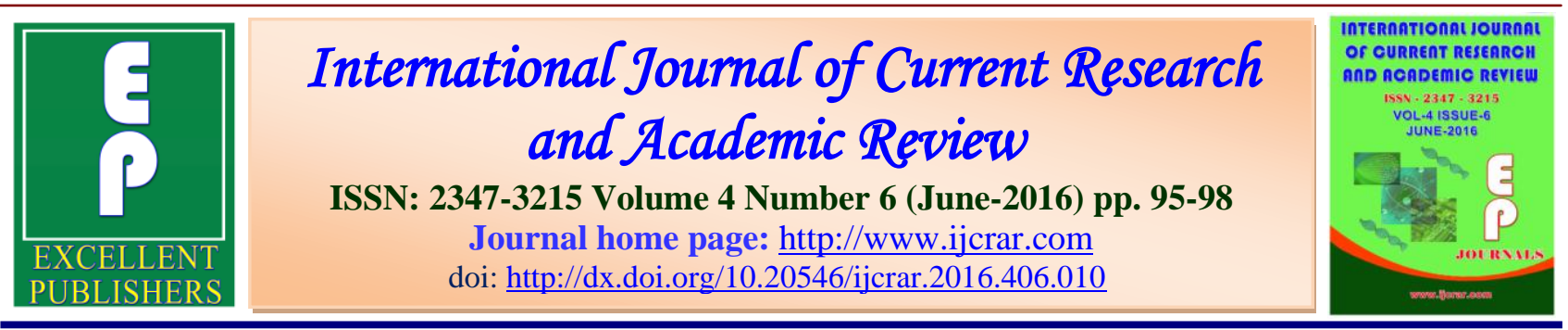

\title{
Investigation of Simultaneous Biosorption of Zinc(II) and Nickel(II) Ions on Flyash from Binary Metal Mixtures
}

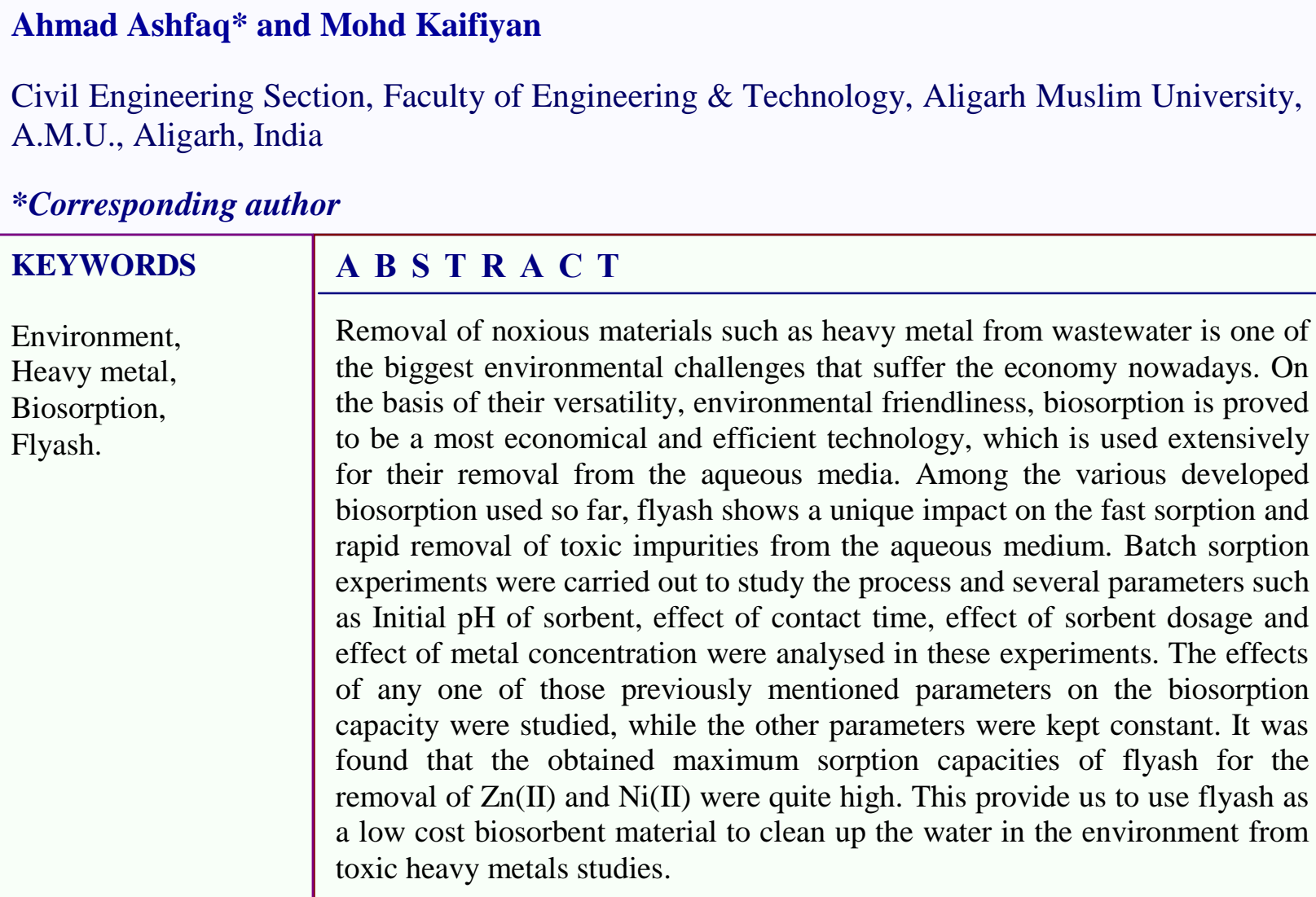

\section{Introduction}

Increasing presence of heavy metals in waste stream and ground water has become one of the most serious environmental pollution problems due to their acute toxicity and non-biodegradable nature. These metals have cumulative effects and tend to accumulate in the living organisms causing various diseases and disorders. They are non-essential and non-biodegradable, and slowly accumulate in the body, usually from foods (Srivastava et al., 2006).
Various researches have been conducted for the removal of heavy metal ions before discharged to receiving sink. The treatment of this type of wastewater involves various techniques such as filtration, solvent extraction, adsorption, precipitation, ion exchange, biological treatment and destructive techniques such as ozonation and oxidation (Sekhar et al., 1998; Kim et al., 2006; Mavrov et al., 2006; Murathan et al., 
2006; Covaco et al., 2007). Adsorption technology using activated carbon is currently being used extensively for the removal of hazardous pollutants from gaseous and liquid phases. The main disadvantages associated with this adsorbent are the high regeneration cost, intraparticle resistance in adsorption process and poor mechanical strength (Aravindhan et al., 2006). Recently, adsorption has attracted considerable interest especially from lowcost materials. Coal fly ash, is obtained from the combustion of powdered coal as waste product and is a very attractive alternative because it is cheap, widely available and has been reported to have good mechanical stability (Potgiester et al., 2009) and requires little processing to increase its sorption capacity. The effects of any one of those previously mentioned parameters on the biosorption capacity were studied, while the other parameters were kept constant. It was found that the obtained maximum sorption capacities of flyash for the removal of $\mathrm{Zn}(\mathrm{II})$ and $\mathrm{Ni}(\mathrm{II})$ were quite high.

\section{Materials and Methods}

\section{Preparation of Binary Metal Mixtures}

The applicability of the empirical Freundlich model to the biosorption of $\mathrm{Zn}$ (II) and $\mathrm{Ni}$ (II) ions from the binary metal mixtures by flyash was checked for different sets of data. The initial concentrations of $\mathrm{Zn}$ (II) ions were varied between 25 and $100 \mathrm{mg} \mathrm{L}^{-1}$, whereas the $\mathrm{Ni}$ (II) ion concentration in each metal mixture was held constant at 10, 20, 50 , or $80 \mathrm{mg} \mathrm{L}^{-1}$. The $\mathrm{pH}$ of ternary metal mixtures was adjusted to $\mathrm{pH} 5.0$ with $1 \mathrm{~mol}$ $\mathrm{L}^{-1} \mathrm{HNO}_{3}$.

\section{Biosorption Studies}

Batch equilibrium sorption experiments were carried out using standard batch methodology. The flyash was mixed with
$100 \mathrm{~mL}$ of the desired metal solution in an Erlenmeyer flask. The flasks were agitated on a shaker at $22^{\circ} \mathrm{C}$ for $2.5 \mathrm{~h}$, which is sufficiently long for sorption equilibrium. Agitation rate was $150 \mathrm{rpm}$. Subsequently, samples were taken at 15 min intervals at the beginning of biosorption and at $30 \mathrm{~min}$ intervals after samples reached equilibrium. The samples were filtered was used for metal analysis.

\section{Results and Discussion}

\section{Biosorption potential of binary mixtures containing $\mathrm{Ni}(\mathrm{II})$ and $\mathrm{Zn}(\mathrm{II})$}

The effects of the presence of $\mathrm{Zn}$ (II) ions on the biosorption of $\mathrm{Ni}(\mathrm{II})$ ions was investigated in terms of equilibrium isotherm and biosorption yield. A comparison of the biosorbed quantity of $\mathrm{Ni}$ (II) ions per unit weight of flyash at equilibrium between the solutions with $\mathrm{Zn}$ (II) ions present as the single metal and with the presence of increasing concentration of $\mathrm{Ni}$ (II) ions is presented in Fig1, in which the results indicated that the equilibrium uptake of $\mathrm{Zn}$ (II) ions decrease (2.62-1.48 $\mathrm{mg} / \mathrm{g})$ with increasing concentration of $\mathrm{Ni}(\mathrm{II})$ ions $\left(10-50 \mathrm{mgl}^{-1}\right)$. In the single metal-ion situation, the maximum uptake of $\mathrm{Ni}$ (II) obtained at initial concentration is $50 \mathrm{mg} / \mathrm{L}, \mathrm{pH} 5.9$ was found to be $12.92 \mathrm{mg} / \mathrm{g}$, while the uptake obtained in the binary metal solutions at the same initial concentration and biosorption conditions, were found to 1.36 to $8.22 \mathrm{mg} / \mathrm{g}$ when concentration of $\mathrm{Zn}$ (II) ions varied from $10-50 \mathrm{mgl}^{-1}$, respectively. In addition, the biosorption yield decreased from 21.18 to $13.31 \%$, at the same operating conditions. As shown Fig 13, maximum uptake of $\mathrm{Zn}$ (II) ions in the single-ion system was $46.58 \mathrm{mg} / \mathrm{g}$ at initial concentration of 100 $\mathrm{mg} / \mathrm{L}$. At the same time, maximum uptake of $\mathrm{Zn}(\mathrm{II})$ in the $\mathrm{Ni}(\mathrm{II})-\mathrm{Zn}$ (II) binary system varied from $1.32-7.14 \mathrm{mg} / \mathrm{g}$ when $\mathrm{Ni}(\mathrm{II})$ ions 
were 10, 2030,40 and $50 \mathrm{mg} / \mathrm{l}$, respectively. A fixed quantity of flyash offered a limited number of surface binding sites, some of which were expected to be saturated by the competing metal ions, at high concentration of them. In addition, this phenomenon might not only result from the saturation of the biosorbent but to the ability of metal ions studied to compete for the biosorption sites. In order to assess that whether the metal ion combinations were interacting in an antagonistic synergetic form, the biosorption outputs of single and multi-ion systems were also compared.

Figure.1 The empirical Freundlich biosorption isotherms of $\mathrm{Ni}(\mathrm{II})$ [pH: 5.9] in the presence of increasing concentrations of $\mathrm{Zn}$ (II).
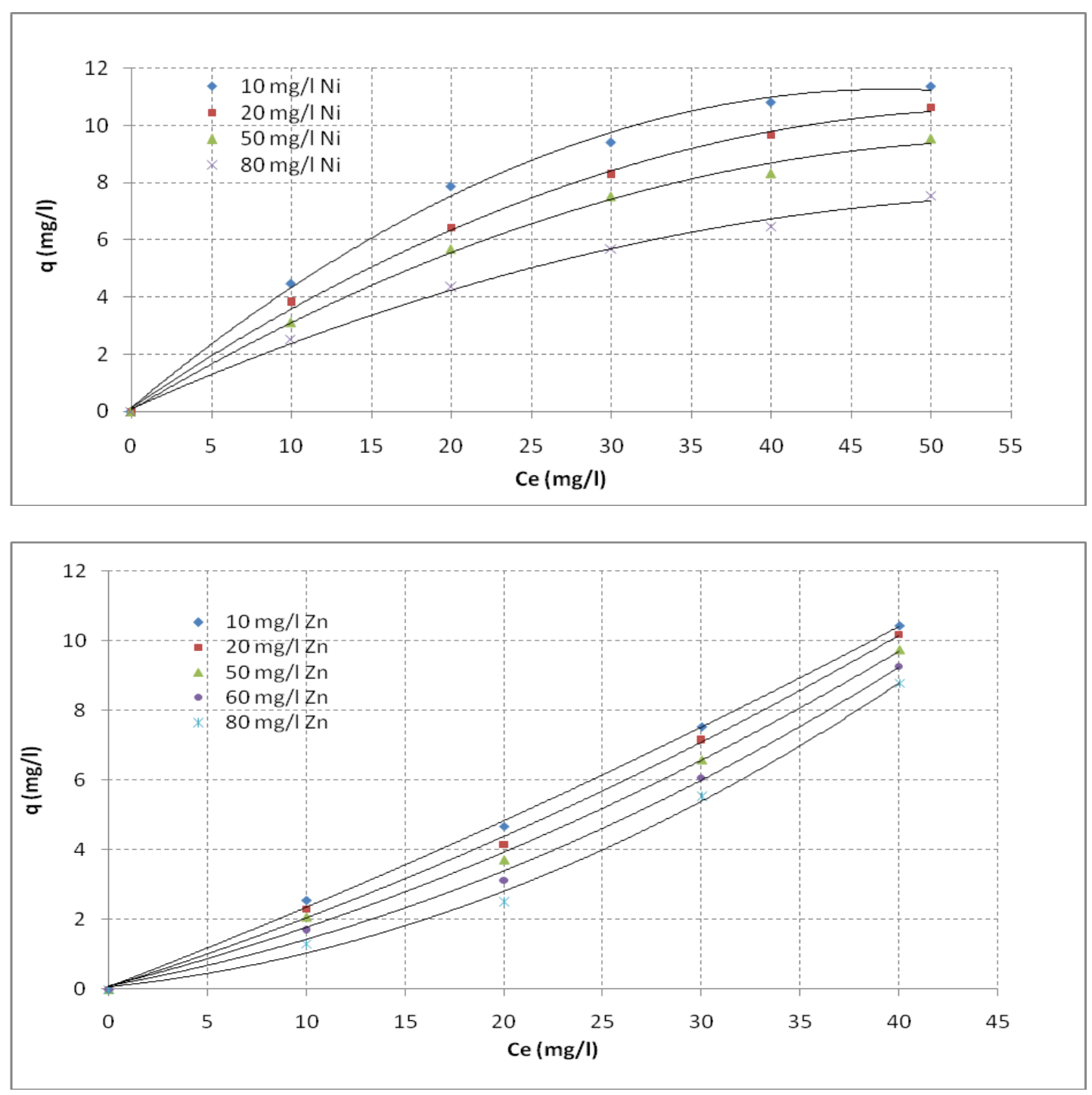

Result, showed that the effect of the mixture was found to be less than that of each of the individual effects of the toxic metal ion, therefore the interaction between $\mathrm{Ni}$ (II) and $\mathrm{Zn}$ (II) could be considered to be antagonistic, and explained as being the competition for sorption sites on flyash, at optimum $\mathrm{pH}$. The simultaneous biosorption phenomena were expressed by the competitive Freundlich biosorption model. 
This shows that the metals in binary metal solution compete for binding sites that are not specific and limited to a maximum binding capacity.

\section{Conclusion}

The present study proves the capability and effectiveness of flyash as a biosorbent for heavy metals removal. Adsorption behavior of $\mathrm{Zn}$ (II) and $\mathrm{Ni}$ (II) were affected by experimental parameters such as $\mathrm{pH}$, contact time and initial concentration of ions solution. It was found that sorption isotherms were better described by Freundlich model for both metal ions. The maximum biosorption capacity values of $\mathrm{Zn}$ (II) and $\mathrm{Ni}$ (II) ions in a mixture of two ion metals with flyash, estimated from model were 11.74 and $10.42 \mathrm{mg} \cdot \mathrm{g}^{-1}$ respectively.

\section{Acknowledgement}

This research was financially supported by the Council of Science \& Technology, Uttar Pradesh (C.S.T. U.P, Lucknow) with Project Gant No: C.S.T. / D.1440.

\section{References}

Aravindhan, R., J.R. Rao, and Nair, B.U. 2006. Application of a chemically modified green macro alga as a biosorbent for phenol removal, Environ. Manag., 90(5): 1877-83.

Covaco, S.A., S. Fernandes, M.M. Quina and Ferreira, L.M. 2007. Removal of chromium from electroplating industry by ion exchange resins, J. Hazardous Materials, 144: 634-638.

Kim, H., K. Baek, J. Lee, J. Iqbal and Yang J. 2006. Comparison of separation methods of heavy metal from surfactant micellar solutions for the recovery of surfactant. Desalination, 191: 186-192.

Mavrov, V., S. Stamenov, E. Todorova, H. Chmiel and Erwe, T. 2006. Removal of nickel ions from wastewater by $\mathrm{Mg}$ $(\mathrm{OH})_{2} / \mathrm{MgO}$ nanostructures embedded in $\mathrm{Al}_{2} \mathrm{O}_{3}$ membranes, Alloys Compd., 426: 281-285.

Moyo, M., L. Muguni and Nyamunda B.C. 2012. Optimisation of Copper and Zinc ions Removal from Aqueous Solution by Coal Flyash as an Adsorbent. IJEST, 4(04): 1760-1766.

Murathan, A.S., Butun, M. 2006. Removal of lead ions from dilute aqueous solution in packed columns by using natural fruit shells through adsorption. Fres. Environ. Bull., 15(12a): 1491-1498.

Potgiester, J.H., S.O. Bada and PotgiesterVermaak S.S. 2009. Adsorptive removal of various phenols from water by South African coal fly ash. Water South Africa, 35: 89-96.

Sekhar, K.C., S. Subramanian, J.M. Modak and Natarajan, K.A. 1998. Removal of metal ions using an industrial biomass with reference to environmental control, Int. J. Mineral Processing, 53: 107-120.

Srivastava, V.C., I.D. Mall and Mishra. I.M. 2006. Modelling Individual and Competitive Adsorption of Cadmium(II) and Zinc(II) Metal Ions from Aqueous Solution onto Bagasse Fly Ash, Separation Sci. Technol., 41(12): 2685-2710.

\section{How to cite this article:}

Ahmad Ashfaq and Mohd Kaifiyan. 2016. Investigation of Simultaneous Biosorption of Zinc(II) and Nickel(II) Ions on Flyash from Binary Metal Mixtures. Int.J.Curr.Res.Aca.Rev. 4(6): 95-98. doi: http://dx.doi.org/10.20546/ijcrar.2016.406.010 